\title{
The Implementation of Teaching Speaking for Students with Hearing Impairment
}

\author{
Melina Anggraeni*, Gunarso Susilohadi, Muh. Asrori \\ English Education Departement, Faculty of Teacher Training and Education \\ Sebelas Maret University
}

e-mail: anggraeni.melina.ma@gmail.com

Abstract

The aim of this article is to report the result of a study about the implementation of teaching speaking for students with hearing impairment. Speaking as one of skills in using a foreign language is now necessary to be taught, including for the students with hearing impairment because of the effect of global competition nowadays. The method used in this research was descriptive qualitative method. The research was conducted at the eleventh grade students of SLB-B YPPALB Magelang academic year 2013/2014. The data were collected through the use of interview, observation, and document analysis. Based on the finding of this research, it can be concluded that: (1) the teacher has implemented the pre-activity, main activity, post activity and the evaluation based on the lesson plan made although he sometimes improves it according to the classroom condition, (2) There were 3 types of problems faced during the teaching-learning process which were students' problem, the teacher's problem and the problem on the school management, (3) there were some solutions proposed by the teacher to cope with those problems.

Keywords: teaching speaking, English, hearing impaired, students.

Abstrak

Tujuan artikel ini adalah melaporkan hasil dari penelitian mengenai pembelajaran berbicara bahasa Inggris untuk siswa tunarungu wicara. Berbicara sebagai salah satu kemampuan dalam berbahasa asing sekarang ini perlu diajarkan termasuk untuk siswa tunarunguwicara agar mereka mampu bersaing secara global sekarang ini. Metode yang digunakan dalam penelitian ini adalah deskriptif kualitatif. Penelitian ini dilakukan di kelas sebelas SLB-B YPPALB Magelang tahun pelajaran 2013/2014. Sumber data penelitian ini berupa peristiwa,informan dan dokumen. Data dikumpulkan melalui wawancara, observasi dan analisis dokumen. Berdasarkan hasil penelitian tersebut, dapat disimpulkan bahwa: (1) guru telah mengimplementasikan 3 langkah kegiatan pembelajaran seperti pre-aktivitas, aktivitas utama dan post-aktifitas berdasarkan rencana pelaksanaan pembelajaran walaupun ada improvisasi tergantung kondisi kelas, (2) ada 3 jenis permasalahan yang dihadapi ketika proses pembelajaran berlangsung yaitu masalah pada siswa, masalah pada guru dan masalah pada manajemen sekolah, (3) ada beberapa jenis penyelesaian yang telah disarankan oleh guru dalam menghadapi permasalahan-permasalahan tersebut.

Kata kunci : pembelajaran berbicara, bahasa Inggris, tunarungu wicara, siswa. 
English has been chosen as a means of communication for people who have different background of cultures and languages in this world. People use it to spread any information coming from different nations and states. Richards (2001:23) says "English is increasingly important in international trade and commerce". This phenomenon brings people to the consideration of the urgent need of comprehending English nowadays. Those reason make the school system from countries around the world require students to learn English for information and communication access and also for the eventual ability to compete economically and professionally (Grabe: 2009:6).

Indonesia as one of active participants of world trade and business needs a good English skill for its citizens in order to interact with colleagues from abroad. Ministry of National Education has decided that English should be taught in High School as a compulsory material. It is implemented not only in regular schools but also Special Educational Schools.

Students of Special Educational Schools deserve the same treatment and service for any educational level that they need. Based on international and Indonesian regulation, people who have any impairment also have the same right to have education. According to Indonesian Constitutional Law in Undang-Undang Dasar 1945 Section 31 sentence 1 (amendment) " Setiap warga Negara berhak mendapat pendidikan". It means that all of Indonesian citizens without any exception have the same right to get a proper education including students with disabilities. They need a special schools that develop their skills and abilities. It is based on the Legislation Number 20 year 2003 about National Education system which states “ Warga Negara yang memiliki kelainan fisik, emosional, mental, intelektual, dan/atau sosial berhak mendapat pendidikan khusus" (Section 5 second sentence).

The comprehension in mastering English is divided in to four skills. According to Widdowson (1978: 57), those four skills in English are: understanding speech (listening), speaking, reading, and writing. They are the skills which are used to respond or create a conversation in social life.

Speaking is one of the main skills that students need to use a language. "Speaking in a second or foreign language has often been viewed as the most demanding of the four skills" (Bailey and Savage in Celce-Murcia, 2001: 103). The 
main goal of people using a language is to be able to communicate with others and speaking will reflect what they have practiced.

However, it is well-known that students who have hearing impairment will have some difficulties in learning and practicing language, both their mother tongue and even for foreign language especially in listening and speaking. The absence of their ability to hear or listen will obviously be a big problem in learning how to speak English too. On the other hand, the developments of modernization and globalization era nowadays demand people to be able to use international language. It is also possible for people who have hearing impairment to go international to publish the result of their work or creation. They also have rights to study abroad, expand their career and future or meet new people from different countries. Thus, the use of English is needed, both orally or written.

Santoso (2012:36) states “Pada pembelajaran tunarungu yang paling utama dan terutama adalah pembelajaran bahasa. Pembelajaran bahasa ini diperoleh melalui percakapan". It can be said that the most important process of the learning activities for hearing impaired students is the language learning. The language learning process can also be obtained by the use of conversation. The teacher must have a good technique to teach speaking which is suitable for hearing impaired students

One of the exceptional schools which has implemented teaching English speaking for hearing impaired students is SLB-B YPPALB which is located in Magelang. This school is focused on teaching students who have disability on hearing and speaking. But the teaching of English speaking has been conducted for the students in the level of Junior and High School. The teacher uses his own techniques and ways to make students be encouraged to try speaking using English. This will be a good reference for other special schools which have not taught English speaking for hearing impaired students.

In defining exceptional students, Hewwet and Forness (1984:75) states that exceptional learner is an individual who, because of uniqueness in sensory, physical, neurological, temperamental, or intellectual capacity and/or in the nature or rage of 
previous experience, requires an adaptation of the regular school program in order to maximize his/her functioning level.

One of those exceptional children is students with hearing impairment. Dwidjosumarto (1995:27) defines hearing impairment as a condition when people lose his hearing that causes problems in receiving any stimulus especially using his ears. Gaurgiulo (2012:397) says that hearing impairment is a general term which is used for describing disordered hearing. In general, people with hearing impairment since they were born usually have speech impairment too as they do not have any input for acquiring a language to conduct a communication. Thus, they have to be well-educated in order to develop their ability.

In general, there are two types of education system to teach hearing impaired students, they are segregated and integrated education system. Segregated system is the education of hearing impaired students which is separated from those who have normal hearing. This means, the service and instruction are special and different from students in general. Teachers in this type of education system also apply different methods and techniques in conducting teaching and learning activity.

While integrated education system is a system which gives opportunity for hearing impaired students to learn together with normal hearing students in the same school (Dwidjosumarto, 1995: 59).

Both in segregated or integrated schools, students with hearing impairment are taught using standard method in speaking which are oral method, manual/sign method and total communication method. Oral Method is a method that gives chance for hearing impaired students to get involved in verbal communication in the normal hearing environment. Based on Watson in Priyono (2012:10), oral method itself is a communication system which uses speech, remaining hearing ability, lipreading, vibration stimuli, and grouping for a spontaneous conversation or an education system where teaching and learning activity are conducted by using spoken and written language.

The other method in teaching speaking for hearing impaired students is manual/sign method. This method emphasizes the use of the hearing impaired students' visual to catch gestures or finger spelling to communicate. It is different with total 
communication method which combines the use of those two methods before. Denton in Dwidjosumarto (1995:167) defines that total communication method is the entire spectrum of the mode of sign language made the children, standardized sign language, speech, speech reading, writing and residual hearing.

The writer considers that mastering English language and its four skills including for hearing impaired students, is important and it brought her to conduct that research. This article is aimed to report the result of a study about the implementation of teaching speaking for students with hearing impairment. It is about (1) how is implementation of English speaking class for students with hearing impairment at the eleventh grade of SLB-B YPPALB Magelang, (2) what problems occur during that process and (3) what kind of solutions proposed by the teacher regarding to that problems.

\section{Research Method}

The writer used the descriptive qualitative method in this research. Descriptive research describes and interprets events, condition, or situation, of the present. Best (1981:93) states that descriptive research is concerned with condition or relationship that exists, opinions that are held, processes that are going on, effects that are evident, or trends that are developing. According to Lofland and Lofland (1984) in Moleong (2006: 157), sources of data in qualitative research are words and actions, the additional data can be documents or other sources. The information can be taken from four sources, namely: events, participants, setting and documents or artifacts (Spradley, 1980: 39- 41).

The research was conducted from April to June at the eleventh grade of SLB-B YPPALB Magelang. The event in this research was in the form of teaching speaking of English in the classroom. The informants were the English teacher and the eleventh grade of the senior high school students of SLB-B YPPALB Magelang in the Academic Year of 2013/2014. The documents were books used by the teacher, syllabus, and lesson plans.

The technique used to check the validity of the data has been gotten was triangulation. Olsen (2004: 3) says that triangulation is the mixing of the data or method so that the diverse viewpoints or standpoints cast light upon topic. According 
to Sukardi (2006:106), triangulation can be defined as the combination of some method or data source in a single study. In this research, the writer had chosen and taken the data sources of triangulation from the teacher, students of the eleventh grade of Senior High School Students of SLB- YPPALB Magelang in the Academic Year of 2013/2014, and the writer himself as an independent observer. The triangulation of the method was performed by clarifying the data obtained through interview, observation and document review.

The Interactive model of analysis by Miles and Huberman (1992) was used to analyze the data gotten in this research. It has some steps which are collecting the data, reducing data, displaying data, and drawing/ verifying conclusions.

The first step was collecting the data which was gotten from interviews, observations, and document analyses. The next step was reducing the data by selecting, focusing, and simplifying the data. Those data then were presented and displayed by arranging those data in the form of description to be finally concluded and verified.

\section{Findings and Discussions}

From the result of the research, it can be known that teaching and learning of English speaking for hearing impairment students is based on the standard competences and basic competences in the lesson plan. The lesson plan is developed based on the school curriculum (KTSP /Kurikulum Tingkat Satuan Pendidikan). Badan Standar Nasional Pendidikan or BNSP has formulated the goals on the Content Standard (Standar Isi) for Senior High Special School Type B (SMALB-B).

The standard competences and basic competences are on the target for the development of students' functional level of literacy. This means that in their daily life, students should be able to use English to communicate with other people orally and in written form. To reach this level of proficiency students should practice speaking, listening, reading, and writing in English.

In order to reach those goals, the process of teaching and learning of speaking is conducted. "Dalam prosesnya, bahasa lisan merupakan alat untuk mencapai tingkattingkat literasi ini." (SI BNSP, 2006: 273). So, the implementation of this speaking class is prepared and applied based on those goals.

Teaching and learning process of speaking for students with hearing impairment is divided into three stages which are planning or preparation, implementation and 
evaluation. This preparation step is aiming at preparing the teaching and learning process to be effective in its implementation. A good teacher makes a good preparation or planning what to be taught for his/her students. The teacher has prepared his teaching and learning process in the classroom by making a lesson plan based on the Standard Competences and Basic Competences according to the syllabus. Besides, he prepared the media and material which are needed to conduct the teaching and learning process. The use of those creative techniques has enhanced the students' motivation and interest in learning English speaking.

For the additional consideration, the teacher usually makes use of the information about students' residual hearing to arrange students' seat in the class decide the appropriate materials for them. The school usually has the hearing test to determine the level of their hearing impairment. It is useful for the school to decide the method and technique to teach them.

Based on the result of the hearing test, the teacher organizes the class and finds the best way for them to achieve the goal. For example, the teacher makes a plan for the arrangement of the students' seat based on their residual hearing. The students who are totally deaf are usually put in the front table because they need more attention from the teacher and maximize their visualization to understand the materials and catch the lesson. While the students with low hearing are put in the back seat because they still be able catch what is said by the teacher. The teacher also recommends the use of the hearing aid for the students with certain hearing level as it helps them to develop their ability in learning a language. Those preparations are done after conducting the test.

After the preparation is done, the implementation or application is executed. The activities which is usually conducted are demonstration and drilling for stating some words or sentences by individual or group working, the use of the combination between lip reading and signing language, making improvisation on the use of lesson plan for teaching and learning activities in class as long as it is relevant to the standard competences and basic competences and giving more intensive guidance for the students with residual hearing ability in developing their skills.

However, the activity in the implementation stage is divided in to three which are pre activity, main activity and post-activity. In pre-activity, the teacher starts the teaching and learning process by giving background knowledge about the skills that 
they need to learn in practicing English, especially in speaking for hearing impaired students. The teacher also gives motivation and explains the reasons why they need to learn the materials of the day. After the students feel encourage to start the lesson, the teacher does a scaffolding task to start entering the material. If they have learned the material in the previous meeting, Mr. Budi as their teacher will review the material in from previous meeting to recall students' memories.

After the pre-activity is successfully conducted, the next is main activity. For the main activity, there are two kinds of activity for the speaking class. The teacher differentiates the way he teaches when he is in the classroom and in the Bina Wicara or Speech Therapy room. It needs a different treatment. The activity in the regular classroom is about learning the theory, modelling and preparation before going to the speech therapy room. In that room, the students are intensively treated how to pronounce and speak by the help of the media provided in that place like mirror, blackboard, speaker, and laptop. The teacher usually provides the materials from the laptop or book, giving the model of speaking to the students, guide them to practice and imitate it in the mirror.

In the post- activity, there are some activities which are done by the teacher and the students after finishing the practice of imitating how to pronounce some words and what they have learned at that day. The teacher checks their comprehension by giving some questions regarding to their speaking practice at that day, sums up the materials and gives a closing statements to re-motivate the students.

To measure the students' performance and comprehension in learning, the evaluation is needed. The evaluation has been done by conducting two kinds of assessment which are formative and summative test. Formative test is the test which is used for evaluating students in the process of forming their competencies and skill with the goal of helping them to continue that growth process while summative test is the test which is aimed at measuring or summarizing what a student has grasped, and typically occurs at the end of a course or unit instruction. (H.J Giono, 1993: 37).

The teacher conducts formative test by evaluating directly when they are asked to repeat the words or sentences form the teacher. When students make any mistakes, the teacher directly corrects it until the students understand the right 
pronunciation of the words or sentences they are spoken. In the Speech Therapy or Bina Wicara room, it is purposively designed to evaluate and give feedback to the students about their speaking skill since that room is also facilitated by mirror and blackboard to support the teaching and learning process.

The summative test is conducted by the teacher to measure how far the students have mastered their speaking skill. The teacher usually makes some scoring rubric and target about how many words the students be able to speak. Since hearing impaired students are unique because they are different from the normal ones, the the teacher makes his own criteria to assess his students. According to Geers (2006) in Gargiulo (2012), the educational achievement of students with hearing impairments may be significantly delayed if it is compared with the hearing students.

Teacher BS considers that his students are still categorized on the "imitative" speaking performance because they are studying how to repeat words or sentences using right pronunciation. So, the assessment is also conducted by testing their speaking skill in repeating some words. The teacher usually makes the target or list of words that the students have to speak. Then, the score will be taken according how many words the students can master and speak well. To decrease the feeling of discouragement of the students, usually the test is conducted in a closed room and the teacher will motivate them in the end of test.

It is obvious that the teaching of English speaking for students with hearing impairment is not easy and has some problems. The problems that occur can be denied since it naturally happens as the consequences of teaching speaking for students who have a problem in getting input for conducting a communication. The problems are divided in to three which are students' problem, the teacher's problem and the problem on the school management.

The students' problem is problems which happen to the students during the teaching and learning of English in the classes. They are nine problems that most occur to them. The first is the students' ability to comprehend complex sentences. It is commonly known that students with hearing and speech impairment have difficulty in arranging sentences since they have limited input of words and sentences. The solution applied by the teacher is by giving intensive practices and guidance. It is obvious 
because the students have poor vocabulary as the result of limited input of the language. Blackhurst and Berdine (1981: 194) states that a hearing loss can also result in poor diction. The second problem is the wrong pronunciation and students' speech. The solution is giving the exercise and feedback-correction of every speech.

The second problem is students' difficulty in making complex sentences. Students with hearing and speech impairment often use simple sentences and signing language in their daily life. So, it is not easy for them to learn foreign language with the use of sentences like what the normal people do. The teacher tries to solve that problem by trying to give the material from the simplest one.

Another problem is misplaced structure of sentences and giving feedback and corrections is the solution applied by the teacher. The teacher always gives them feedback and correction whenever and wherever the teacher knows the students make any mistakes in arranging sentences. Thus, after the process of giving them much input, they know how to structure good sentences which are acceptable to conduct a communication.

The difficulties in pronouncing some sounds especially those which needs vibration also become a problem. One of the weaknesses of students with hearing impairment which affects their process in learning English speaking is the production of sounds. Since they have no ability in listening to those sounds, they will not be able to know how to imitate it. The solution is by maximizing the use of supporting equipments and intensive practices. The next problem is students are confused to understand different writings and sounds in English. Learning English is different from learning Bahasa Indonesia. The different way of writings and pronouncing caused a problem for the students. To cope with that, the teacher writes how the word should be pronounced.

The possibility of the decreasing level of students' hearing ability is another problem that occurred. Disability in hearing ability sometimes is getting better or getting worse. It is getting better when the people with hearing impairment pay special attention to have treatment and therapy to improve their condition. But, if the hearing impaired people do not check their condition regularly, there will be a possibility that they have some decreasing level of hearing ability. The solution proposed by the teacher is by giving sound and medical teraphy along with the use of hearing aid. 
Sometimes, students who are easily get bored during teaching and learning of speaking class is also a problem. The teacher deals with that problem by giving a break and talking about their interest or hobbies. The teacher tries to get closer to his students. It is in line with what is said by Larsen-Freeman (2000: 94) "building relationship with and among students is very important".

The last students' problem is about their different ability and concentration in following the class. It is similar with what is stated by Permanarian Somad and Tati Hernawati (1996 : 157) "generally, hearing impaired students have normal or average intelligence, but because intellectual development is strongly affected by language development, it makes the hearing impaired students will show low intelligence that is caused by the difficulties in understanding the language". The solution is creating an interesting atmosphere in the class for engaging their attention and maximizing their visualization according to their needs.

Those problems occur as the consequence of teaching speaking of English for hearing impaired students. Edja Sadjaah (2005) in Priyono (2012: 2) states that many researches about the correlation between hearing impairment and many kinds of psychological aspects such as cognition, emotion, social, motoric development, and personalities are caused by the lateness and poverty of language mastery development as the result of the impairment.

Besides the problems that occur to the students, there are also problems that happen to the teacher of English in conducting the teaching and learning process. There three problems which occur. The first is the English teacher's background is not from English education program. The teacher does not have experience in teaching English because the background of his study is on handling students with special needs. It sometimes causes him to be unconfident when teaching English. Dealing with that problem, the teacher tries to always improve self-ability. For the school, it is obviously needed that for the next recruitment the schools or government should look for the professional teacher from the English education program with an intensive training on special education science.

The other problem is that the teacher who considers himself as an incompetence teacher. It's a consequence of recruiting teacher from different educational background 
to teach English. The teacher feels that he has lack of knowledge in teaching English. The solution is by keep trying and doing reflection for improving himself.

The next problems occur during the teaching speaking for hearing impaired students is the problems on the school management. The first is the lack of the appropriate handbooks for the teacher and students. Source of the materials is important for the students and teacher to conduct the teaching and learning activity. Unfortunately, there is no appropriate and suitable book for students to be their guidance in learning English speaking. Its solution is finding other resources and developing the materials from daily life.

The second problem is the difficulties in finding appropriate material which is suitable with what the students need. As the solution, the teacher looks for other sources which suit with the students' need as long as it is based on the standard competences and basic competences used.

The last problem is the lack of the time allocation for the speaking class of students with hearing impairment. The time allocation for students with hearing impairment is $2 \times 30$ minutes in a week. The teacher considers that by the time given, it's not enough to develop students' four skills especially in speaking. It needs more time to give them appropriate treatment to be able to speak. According to Standar Isi from Badan Standar Nasional Pendidikan (BNSP) for SMALB or Senior Exceptional High School, the time allocation for the students to learn English is $2 \times 40$ minutes. Seeing from the situation and students' readiness in learning English, the time allocation should be increased in order to improve their ability in speaking. The teacher tries to maximize the use of 'out-of-class' treatment and practice as the solution of that problem.

Based on the explanation above, it can be said that teaching speaking for hearing impaired students is challenging and demanding more effort than teaching the regular students. Preparation and feed back is necessarily needed for the improvement of students' progress in speaking. The problems which occur during the process of teaching also need applicative solutions from the teacher. 


\section{Conclusion and Suggestions}

From that explanation, it can be implied that teaching English speaking for hearing impaired students is challenging and need a long process to reach its goal. Since teaching speaking for students who are known as hearing and also speech impaired is not easy, the teacher are demanded to be more creative, innovative and patient in facing the situation in the class so that he improves the students ability. The important point of teaching them is to give motivation so that they are ready to learn how to speak and ignore their disability.

It is good to know that the teacher has considered the importance of making a lesson plan and selecting the suitable materials for the students. But, the improvement also should be made dealing with the teacher's competence in speaking English. However, it is one step forward for making the students with hearing impairment in the special school be able using English appropriately not only in written form but also in their speaking for their future life.

Based on the findings and discussions, there are some suggestions for the school, teacher, and students. The school should conduct supervision about how the process of teaching and learning English for hearing impaired students so that it will have a progress, provide appropriate books and resources for the teacher and students to support their teaching and learning process, pay attention about managing and controlling the schedule for the students so that the time for them in practicing English speaking can be added.

The teacher should improve his ability in teaching and managing the class to avoid students' boredom, learn more about English speaking so that it will increase his confidence in teaching speaking for his students, pay more attention on the detail of what is spoken by the students and has a special note to report their progress and improvement.

To the writers, this research is only a brief introduction to a process of teaching and learning of English speaking for hearing impaired students. Hopefully, there will be more advanced writers who will conduct further research about the same topic so that it will improve the process of teaching English for hearing impaired students and find out the solutions for the problems faced in order to improve their English. 


\section{REFERENCES}

Badan Standar Nasional Pendidikan (BSNP). 2006. Standar Isi Untuk Satuan Pendidikan Dasar dan Menengah: Standar Kompetensi dan Kompetensi Dasar SMALB. Jakarta: Depdiknas

Best, John W. 1981. Research in Education. New Jersey: Prentice Hall Inc.

Blackhurst, A. Edward and Berdine, William H. 1981. An Introduction to Special Education. Boston: Little, Brown and Company

Celce-Murcia, Marianne (ed). 2001. Teaching English as a Second or Foreign Language (Third Edition). Boston: Heinle\&Heinle.

Gargiulo, Richard M. 2012. Special Education in Contemporary Society: An Introduction to Exceptionality: fourth edition. USA: Sage Publications.

Grabe, William. 2009. Reading In a Second Language: Moving from Theory to Practice. Cambridge: Cambridge University Press.

Hargio Santoso. 2012. Cara Memahami dan Mendidik Anak Berkebutuhan Khusus. Yogyakarta: Gosyen Publishing.

Hewett, Frank M. \& Forness, Steven R. 1984. Education of Exceptional Learners. Wellesley: Allyn\&Bacon.

Larsen-Freeman, Dianne. 2000. Techniques and Principles in Language Teaching. Oxford: Oxford University Press.

Miles, Mathew. B. and Huberman, Michael. 1992. Analisis Data Kualitatif (Terjemahan Tjejep Rohendi Rosidi). Jakarta: Universitas Indonesia.

Moleong, J. Lexy. 2006. Metodologi Penelitian Kualitatif. Bandung: PT Remaja Rosdakarya.

Olsen, Wendy. 2004. Forthcoming as a chapter in Developments in Sociology. Ormskirk: Causeway Press.

Priyono. 2012. Materi Anak Tuna Rungu. Handout. 
Richards, Jack C. 2001. Curriculum Development in Language Teaching. Cambridge: Cambridge Language Edition.

Sukardi. 2006. Penelitian Kualitatif-Naturalistik dalam Pendidikan. Penerbit Usaha Keluarga.

Spradley, J. 1980. Participant Observation. Belmont, CA: Wadsworth Cengage Learning.

Undang-Undang Dasar Negara Republik Indonesia Tahun 1945

Widdowson, H.G. 1978. Teaching Language as Communication. Oxford: Oxford University Press. 